\title{
A NEW TEIIDAE SPECIES (SQUAMATA, SCINCOMORPHA) FROM THE LATE PLEISTOCENE OF RIO GRANDE DO SUL STATE, BRAZIL
}

\author{
ANNIE SCHMALTZ HSIOU \\ Museu de Ciências Naturais, FZB-RS, Av. Salvador França, 1427, 90690-000, Jardim Botânico, Porto Alegre, RS, \\ Brazil.anniehsiou@gmail.com
}

\begin{abstract}
The fossil record of the Teiidae in South America is restricted almost exclusively to the Cenozoic, with the group mainly represented by Tupinambis during Miocene-Holocene times. Currently, this genus includes the largest lizards of the New World as well as the largest members of the family. Tupinambis uruguaianensis nov. sp., the first fossil squamate from Rio Grande do Sul State, is represented by a right lower jaw, basicranium, three dorsal vertebrae, and a left radius and ulna of the same individual. The material comes from the Touro Passo Formation, where reptiles were previously represented only by Testudines. The new species shares several characters with the living species of Tupinambis, but is distinguished from all them by an articular bone with a deeply concave ventral margin, angular process is more rounded, proportionally larger and projecting beyond the ventral and posterior adjacent limits, and a very protuberant adductor crest so that the lateral articular bone surface is lateroventrally directed.
\end{abstract}

Key words: Squamata, Teiidae, Tupinambis, Late Pleistocene, Rio Grande do Sul State, southern Brazil.

\begin{abstract}
RESUMO - O registro da família Teiidae na América do Sul é restrito quase que exclusivamente ao Cenozóico e o grupo é principalmente representado por Tupinambis, no intervalo Mioceno-Holoceno. Atualmente este gênero inclui os maiores lagartos do Novo Mundo e os maiores membros da família. Tupinambis uruguaianensis sp. nov. é o primeiro Squamata registrado para o Pleistoceno final do Estado do Rio Grande do Sul, Brasil. O material inclui uma hemimandíbula direita, basicrânio, três vértebras dorsais, rádio e ulna esquerdos de um mesmo indivíduo, procedentes da Formação Touro Passo, cujos répteis eram antes representados apenas por Testudines. A nova espécie compartilha muitos caracteres das espécies recentes de Tupinambis, mas distingue-se de todas elas pelo articular com margem ventral marcadamente côncava; processo angular mais arredondado e proporcionalmente maior, projetando-se para além dos limites ventral e posterior adjacentes; e pela crista adutora muito proeminente, resultando numa face lateral do articular voltada látero-ventralmente.
\end{abstract}

Palavras-chave: Squamata, Teiidae, Tupinambis, Pleistoceno final, Rio Grande do Sul, sul do Brasil.

\section{INTRODUCTION}

The Family Teiidae, including nine genera, is today widely distributed in South and Central America and Antilles, but has only one genus in North America (Estes, 1983). Estes (1983) recognized two subfamilies: Polyglyphanodontinae (extinct) and Teiinae (Teiini and Tupinambini Presch, 1974a). Later on, Estes et al. (1988) raised the Tupinambini to a subfamily (Tupinambinae) that included four genera: Callopistes, Crocodilurus, Dracaena and Tupinambis. Currently, members of Tupinambinae do not occur in North America and apparently are restricted to South America (Sullivan \& Estes, 1997). Here, the fossil record is abundant for the Miocene-Holocene interval, where Tupinambis predominates, mainly in Argentina (Donadio, 1983, 1984a, Gasparini et al., 1986; Brizuela \& Albino, 2004) and Colombia (Estes, 1961, 1983; Sullivan \& Estes, 1997). Donadio (1985) proposed the name Lumbrerasaurus scagliai for an Eocene tupinambinae from Argentina, on the basis of the cross section of the teeth and subtle differences in the morphology of the dorsal vertebrae, but this was considered a nomem dubium by Sullivan \& Estes (1997). Ameghino (1893) described Diasemosaurus occidentalis and Dibolosodon typicus (Early Miocene of Argentina), relating the first to Chlamydosaurus and the second to the Proterosauridae (in Ameghino's manuscript). Later, Báez \& Gasparini (1977) and Donadio (1983, 1984b) considered Diasemosaurus closely related to Tupinambis, whereas Estes (1983) considered Diasemosaurus a nomen dubium, and Diboloson as "Lacertilia" incertae sedis. Sullivan \& Estes (1997) reevaluated the material of Estes (1961, 1983) from the Miocene of Colombia, and together with new materials from La Venta (Middle Miocene), recognized a new tupinambine: Paradracaena colombiana. Another tupinambine, Callopistes bicuspidatus, was recognized from the Pliocene of Argentina, so far the only record of the genus for South America (Chani, 1976). In Brazil, 
several specimens from the Pleistocene caves of Minas Gerais (Estes, 1983; Souza-Cunha \& Magalhães, 1986; Camolez et al., 2005; Camolez, 2006) and Bahia States (Camolez, 2006) were referred to Tupinambis.

The genus Tupinambis includes the largest living lizards of the New World and the largest teiids. Nowadays, seven species are recognized: T. teguixin (Linnaeus, 1758), $T$. rufescens (Günther, 1817), T. merianae (Duméril \& Bibron, 1839), T. duseni Lonnberg, 1910, T. longilineus Ávila-Pires, 1995, T. quadrilineatus Manzani \& Abe, 1997 and T. palustris Manzani \& Abe, 2000. The distribution of Tupinambis is confined to South America (east of the Andes, and from Amazonia to the north of Patagonia; Peters \& Donoso-Barros, 1970; Presch, 1973; Cei \& Scolaro, 1982; Peres, 2003). This paper deals with the description of a new teiid species of Tupinambis, the first fossil squamate from the Late Pleistocene of Rio Grande do Sul State, Brazil.

\section{LITHOLOGICAL SETTING}

The Touro Passo Formation corresponds to the flood plain deposits of the Touro Passo Creek, Uruguaiana Municipality, extreme west of Rio Grande do Sul State, Brazil (Figure 1A). The formation has yielded freshwater mollusks (Bombin, 1976; Oliveira, 1990; Retamoso et al., 2001), some fragments of chelonians (Bombin, 1976; Maciel et al., 1996), a bird bone fragment (Ribeiro et al., 1995; Hsiou, 2007) and mostly a large number of Pleistocene mammals (Bombin, 1976; Oliveira, 1992, 1996, 1999). Bombin (1976) proposed that the formation had two members: (i) a lower, conglomeratic level, deposited in erosive discordance on basalt of the Serra Geral Formation, with rolled fossils of mammals (deposition between 13,000 and 12,000 years BP); and (ii) upper, muddy sandstone level, deposited on the previous one, containing most of the mammals fossils (deposited between 12,000 and 3,500 years $\mathrm{BP})$. This member is essentially formed by siltstones or siltic to siltic-clayed sandstones, containing a volcanic ash layer.

New datings carried out by thermoluminescence for the muddy sandstone level (Milder, 2000), indicated dates between 42.000 and 6000 years BP (Figure 1B), showing that the muddy sandstone level of these outcrops may have very distinct ages. As some events of deposition are contemporaneous, while others are not, the muddy sandstone level only exists as a lithostratigraphic unit, rather than representing a "layer" of the same age in all the Touro Passo Formation. Therefore, the dating carried out by Bombin (1976) seems to be valid only for a set of layers of the outcrop (or even of only one), supplying a minimum age for the rock, while the thermoluminescence datings give an average age for the sedimentary packages. The ages show that the depositional cycle is more complex and older. In short, deposition in the Touro Passo Creek was multicyclical, an observable fact in various other sub-basins of the Uruguay River (Da Rosa, 2003). According to Da Rosa \& Milder (2001) the same lithologies of the Touro Passo Formation are found in diverse localities of the extreme west region, indicating uniformity or a depositional similarity during a well-determined

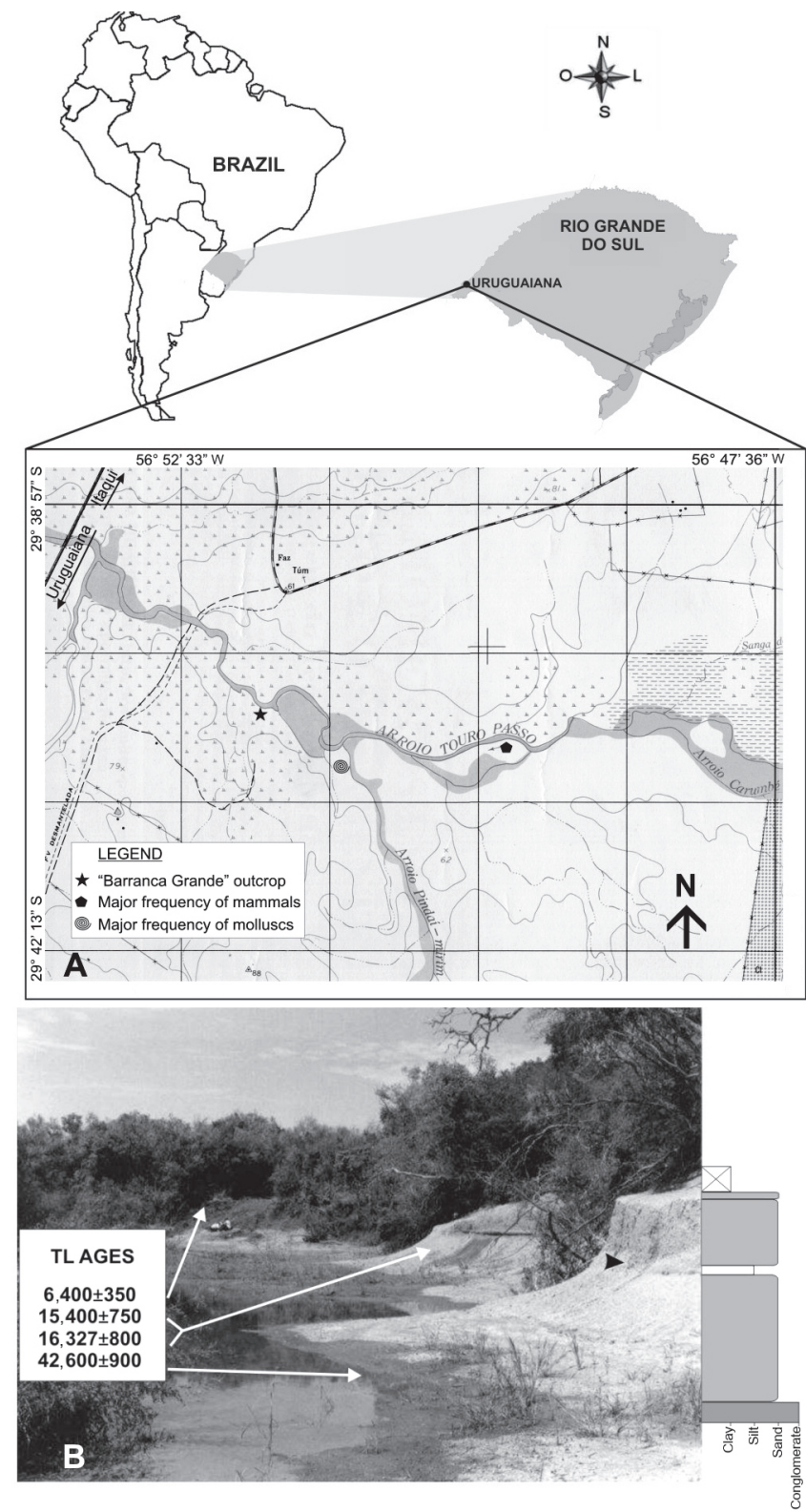

Figure 1. Location map of the main fossiliterous outcrops (A) and the stratigraphic profile of the Touro Passo Creek (B) with thermoluminescence (TL) ages (adapted from Da Rosa, 2003).

interval of time. Da Rosa (2003) recognized a lithological similarity between the Touro Passo Creek, Quaraí Creek and the Sanga da Cruz Creek, all them with a conglomerate level at the base, and a muddy sandstone one at the top. Such deposition could have occurred over a large area, from the extreme west of Rio Grande do Sul State, to the north of Uruguay, and as well as northeastern part of Argentina. Therefore, the Touro Passo, Quaraí and Sanga da Cruz Creeks would have been restricted to a period of about 45,000 years BP (Da Rosa, 2003). The Touro Passo Formation has been correlated with the Sopas Formation (Uruguay), about 30,000 years BP (Bombin, 1976; Ubilla, 1985). However, datings for the Sopas Formation (Ubilla et al., 2004) and the Guterrez Alloformation (Da Rosa \& Milder, 2001), indicated ages between 45,000 and 130,000 years BP. 


\section{MATERIAL AND METHODS}

The lizard material is from the Barranca Grande outcrop, Touro Passo Creek (Figure 1), in the muddy sandstone level of the Touro Passo Formation, from where many mammal remains have been collected (see Bombin, 1976; Oliveira, 1992, 1996, 1999) along with a unique bird fragment (Ribeiro et al., 1995). The lizard material was found associated in the outcrop and consists of a right lower jaw, a braincase and postcranial bones, all of the same individual, deposited in the fossil collection (paleovertebrates) of the Museu de Ciências Naturais da Fundação Zoobotânica do Rio Grande do Sul, under number MCN-PV 2184.

The preservation is good, except for the many breaks and incrustation by $\mathrm{CaCO}_{3}$. The right lower jaw is disarticulated between the angular, dentary and splenial bones, but most bones are present: dentary, splenial, coronoid, surangular, angular and articular. In the braincase, the basioccipital, parabasisphenoid, otooccipital, prootic and supraoccipital bones are present. The postcranium includes three dorsal vertebrae and incomplete left radius and ulna.

The dental and osseous terminology follows Presch (1970, 1974b), Krause (1978a, 1978b), Estes (1983) and Bell et al. (2003). Systematics follows Estes et al. (1988), Sullivan \& Estes (1997) and Nydam et al. (2007).

The fossil material was compared with the available specimens of recent species of Tupinambis (see list of comparative material in the Appendix), mainly with Tubinambis merianae (see Ávila-Pires, 1995), which is the only extant species in the Rio Grande do Sul State (Lema, 1994).

\footnotetext{
Abbreviations

Institutional abbreviations. MCN, Museu de Ciências Naturais da Fundação Zoobotânica do Rio Grande do Sul, Porto Alegre; MCP, Museu de Ciências e Tecnologia da Pontifícia Universidade Católica do Rio Grande do Sul, Porto Alegre; MZUSP, Museu de Zoologia da Universidade de São Paulo, São Paulo; UFRGS, Universidade Federal do Rio Grande do Sul, Porto Alegre.

Anatomical abbreviations. A, angular; AC, articular condyle; AF, articular facet; APA, angular process of articular; ASP, ascending process; BO, basioccipital; BPT, basipterygoid process; BT, basal tubera; C, centrum; CO, coronoid; COT, cotyle; AP, alar process; $\mathbf{D}$, dentary; $\mathbf{F M}$, foramen magnum; IAF, inferior alveolar foramen; NP, neural process; OC, occipital condyle; OL, olecranum; OTO, otooccipital; PBS, parabasisphenoid; PMPC, posteromedial process of coronoid; POZ, postzygapophysis; PP, paroccipital process; PRO, prootic; PRZ, prezygapophysis; RP, retroarticular process; S, splenial; SA, surangular; SBCR, subcircular replacement pits; SBDS, subdental shelf; SC, sulcus dentalis; SIG, sigmoid notch; SO, supraoccipital; SYN, synapophysis; TP, transverse process of neural arch; ZA, zygantrum; ZS, zygosphene.
}

\section{SYSTEMATIC PALEONTOLOGY}

\author{
SQUAMATA Oppel, 1811 \\ SCINCOMORPHA Camp, 1923 \\ TEIIDAE Gray, 1827 \\ TUPINAMBINAE Presch, 1974 \\ Tupinambis Daudin, 1803
}

Tupinambis uruguaianensis sp. nov. (Figures 2-7; Tables 1, 2)

Holotype. MCN-PV 2184, a right lower jaw, a braincase and postcranial bones of a same individual.

Type locality. Touro Passo Formation, Late Pleistocene. "Barranca Grande" outcrop, Touro Passo Creek, Uruguaiana Municipality, Rio Grande do Sul State, Brazil (Figure 1).

Etymology. Specific name uruguaianensis in reference to Uruguaiana Municipality, where the holotype was collected.

Diagnosis. Teiid lizard distinguished from other species of Tupinambis in having an articular bone with a deeply concave ventral margin, angular process more rounded, proportionally larger and projecting beyond the ventral and posterior adjacent limits, and a very prominent adductor crest, so that the articular bone surface is lateroventrally directed.

\section{DESCRIPTION}

\section{Skull}

Supraoccipital. Forming most of the braincase roof, this is nearly hexagonal (Figures 2 and 3 ). In the posterior third, the bone has an area that is only slightly concave dorsally, wider than long, and limited posteriorly by the dorsal margin of the foramen magnum. Its lateral margin is formed by a delicate medial process, near the base of the paroccipital process. Dorsally, the flat surface is laterally limited by a low rounded crest that lies more anteriorly over the suture with the prootic. In the anterior two-thirds of the bone the occipital crest becomes gradually higher and thicker anteriorly, providing the medial limit of a fossa that laterally low crest over the suture of this bone with the prootic. Anterior and ventral to the crest, there is a bone fragment that could correspond to a displaced portion of the ascending process.

Basioccipital. The ventral surface is almost flat, only mediolaterolaterally and anteroposteriorly concave (Figure 2 ). Besides the occipital condyle, the most conspicuous features are the basal tubera, which receive the insertion of the longus capitis muscles (Rieppel \& Zaher, 2000). The middle portion of the condyle is markedly convex ventrally as is the anterior portion. The contact with the exoccipital portion of otooccipital is not visible. The left basal tubera (right side lost) is large, with two surfaces, a smaller posterior one, and a larger ventral one, separated by a thick, and rounded crest that extends almost to the edge of occipital condyle, and that consists of the anterolateral edge of the bone, with sutures suturing with the parabasisphenoid. The free distal portion of the tuber has prominent rounded shape, due to a fused epiphysis. Bell et al. (2003), referred to such epiphyses 

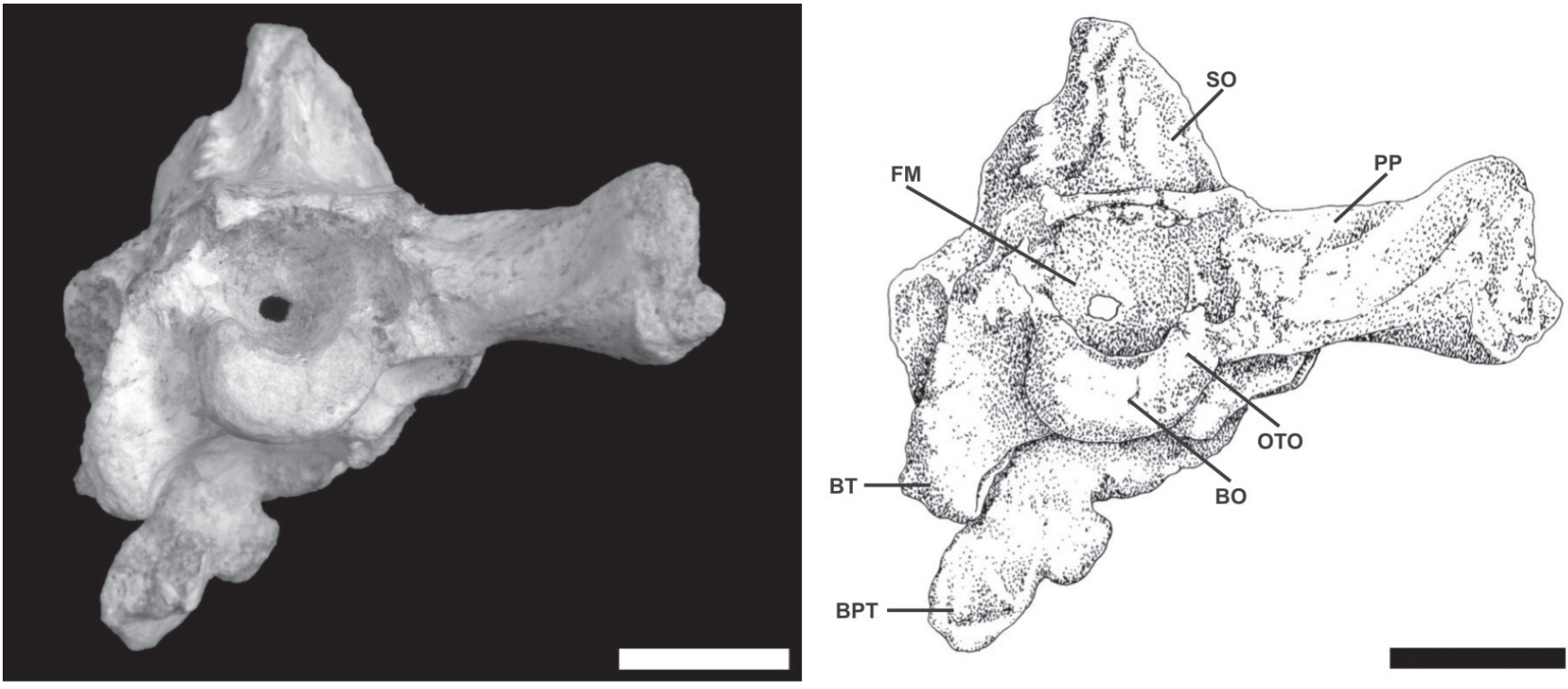

Figure 2. Tupinambis uruguaianensis sp. nov., holotype, MCN-PV 2184. Occipital view of braincase and schematic drawing. Scale bars $=10 \mathrm{~mm}$.

as "apophyseal ossifications". The axis of the basal tubera is oblique to the midline plane and is directed more laterally than ventrally. The ventral limit of the lateral edge of the tuber projects ventral to the occipital condyle. The basal tubera are very thick in the ventral extremity, becoming gradually thinner dorsally, up to the crista tuberalis, although the suture with otooccipital is not visible, due to fusion. The base of the tuber extends anteriorly from this point (bordering the exoccipital portion of the otooccipital) up to the suture with the parabasisphenoid. The left side of the tuber is broken at the base, revealing thick bony walls, with a socket between them. The transverse suture between the basioccipital and the parabasisphenoid is still visible.

Parabasisphenoid. This extremely complex bone is the main component of the braincase floor (Figure 3). The posterior portion is slightly more dorsal than the anterior one and, with the basioccipital, forms the posterior floor of the braincase. Separated from the posterior portion by the dorsum sellae, the anterior portion is evidently more ventral than the posterior one. The limit of the sella turcica is a well-developed transversal crest (crista sellaris), situated between the bases of the alar processes, which are separated by a $8.4 \mathrm{~mm}$ gap. Still in the dorsum sellae, located just ventral to the alar process, is a small foramen for the abducens nerve $(\mathrm{cn}$. VI) . At the base of the sella turcica, in the angle between the dorsum sellae and the sidewalls, there is an oval foramen, for cerebral branches of the internal carotid artery. Anterior to the sella turcica, there is a small bone fragment, dorsally displaced, but a cultriform process seems to be absent. The ventral surface of the bone body is slightly concave, reflecting the concavity of the basioccipital. Between this bone and the basioccipital, there is a weak suture. This is transverse in the central half $(50 \%)$ and inclined posteriorly in its lateral quarter. On the lateral surface of the body of the basisphenoid (medial to the crista prootica, ventral and posterior to the alar process), is the large posterior opening of the Vidian canal (entrance of the internal carotid artery and exit of the palatine branch of the facial nerve, cn.VII), some millimeters anterior to the suture with the basioccipital. The suture between the alar processes of the parabasisphenoid and prootic is not visible. However, it may be marked by a delicate, but welldefined, crest beginning anteriorly at the alar process, extending ventrally through to the lateral face, and continuing as the anterior edge of the crista prootica. The alar processes are rounded and they project several millimeters anteriorly and about $2.7 \mathrm{~mm}$ above the dorsum sellae. The left basipterygoid process (right broken and lost) is broken at its base, and is partially displaced posteriorly and medially. The ventral edge is rounded and thicker posteriorly, but the posterior apophysis of the edge is absent due to breakage. Because of the breaking of the process at its base, the anterior opening of the Vidian canal (exit of the palatine artery, branch of the internal carotid) could not be identified. Some small bone fragments are necklaced to its medial face, and have not been removed to prevent greater damage to the specimen. Prootic. This bone forms the sidewall of the cranial cavity, anterior to the otooccipital (Figure 3). It has a notch in the shape of reclining "V", the incisura prootica (= trigeminal notch of the Oelrich, 1956, for the exit of the $\mathrm{cn}$. V). This bone can be divided into two parts: dorsal and another ventral to the incisura. The dorsal part is high and long, almost quadrangular and more or less flat. Posterior to this part, and forming with it an angle of almost $90^{\circ}$ (concave region of the bone), the prootic continues along a posterolateral process that unites with the anterior surface of the paroccipital process (otooccipital), covering at least its medial two-thirds. Dorsally, this portion is fused to the supraoccipital at the level of a low and rounded crest. In the ventral part of the prootic is the alar process, triangular, high and short. The dorsal edge of the incisura prootica is inclined anteriorly and dorsally, while its 

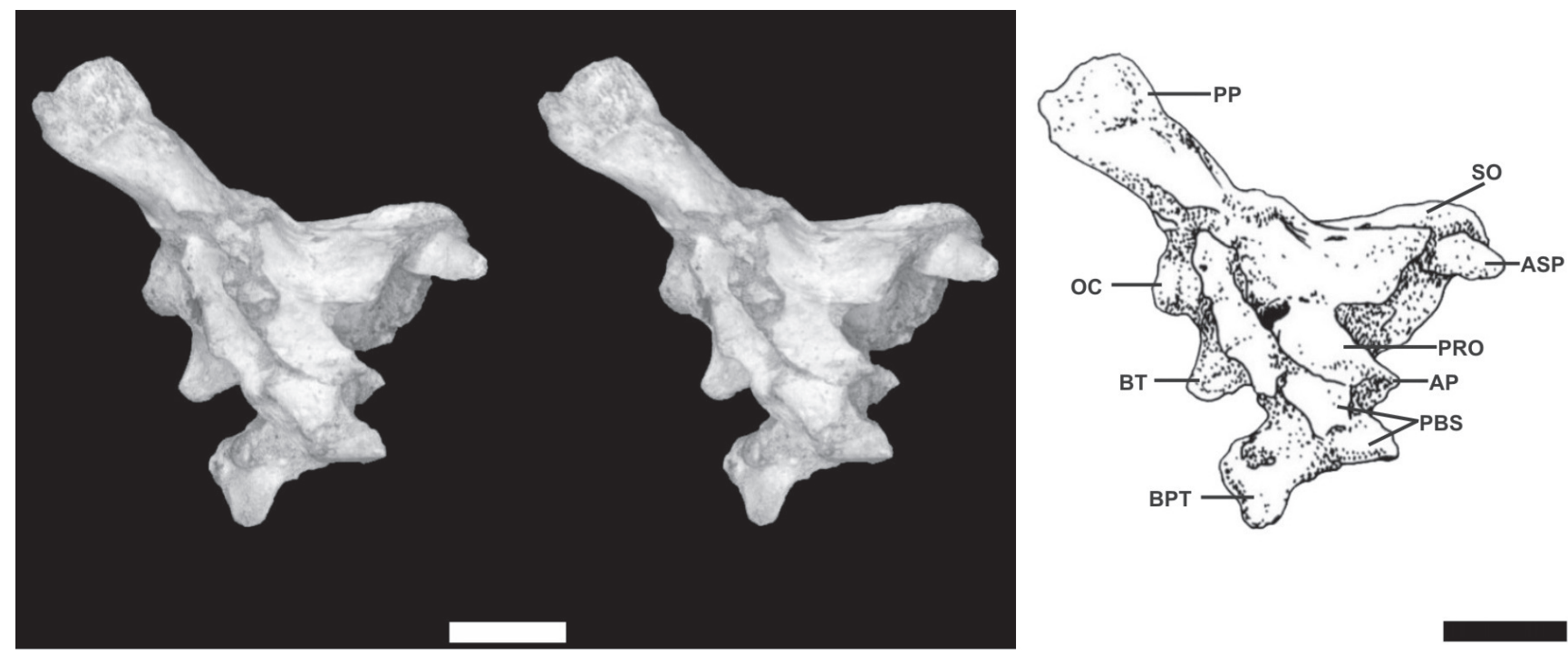

Figure 3. Tupinambis uruguaianensis sp. nov., holotype, MCN-PV 2184. Stereoview and schematic drawing of the lateral region of the braincase. Scale bars $=10 \mathrm{~mm}$.

ventral edge is almost horizontal. The dorsal edge is continued ventrally and posteriorly by a narrow crest, but is relatively high on the lateral surface of the crista prootica, until reaching the ventral edge of the crista prootica. On the other hand, the ventral edge of the incisura prootica forms the edge (dorsal) of the alar process, and extends anteriorly until the posterior limit of the alar process of the parabasisphenoid. The crista prootica is incomplete and broken, but it can be observed as projecting posterodorsally at an angle of nearly $45^{\circ}$ with the horizontal plane. It is very thin, laterally bordering a wide and deep recess, called recessus vena jugularis (Oelrich, 1956). As the crista prootica and the facial nerve foramen (cn. VII) were not shown, it was not possible to determine whether the prootic communicates with the anterior edge of fenestra ovalis, as seen in different lizards.

Otooccipital. This forms most of the posterior surface of the skull, the lateral edge of the foramen magnum and the lateral portions of the occipital condyle, with a typical morphology (Figure 2). The edge does not project more posteriorly than dorsally (supraoccipital), and the dorsal limit of condyle is located just below of the middle portion of the foramen magnum. The most important structures are the openings of the cranial nerves (posterior) and the auditory region (lateral). A triangular fossa is limited by the base of the paroccipital process, the lateral edge of the foramen magnum, and the crista tuberalis. In this fossa, there are three foramina, the largest being dorsal to the other two, of which the medial one is greater that the lateral. The two ventral openings are foramina for the hypoglossal nerve (cn. XII), whereas the dorsal foramen is for the vagus and accessory nerves ( $\mathrm{cn} . \mathrm{X}$ and XI). The crista tuberalis (left, dorsally incomplete), extends from the base of paroccipital process (right preserved, fragmented at base) dorsally, until it fuses with the basal tubera ventrally. As with the tuber, the crista tuberalis is thicker ventrally and decreases in thickness dorsally. On the lateral face of the otooccipital are located the fenestra ovalis (dorsal) and recessus scalae tympani (ventral to fenestra). Both appear oblique, opening in a posterior direction, and havin an oval shape and similar dimensions $(\sim 2.0 \mathrm{~mm})$. The largest diameter of the fenestra ovalis seems to be horizontal, while that of the recess seems to be vertical. The crista interfenestralis is relatively well preserved, but extremely thin (about $0.5 \mathrm{~mm}$ ). Both openings are sufficiently high on the sidewall, which the recess being more or less at the same level as the foramina of the hypoglossal nerve in the posterior face of the braincase. The paroccipital process (right, broken at the base, displaced ventrally and posteriorly) has a flat posterior face. A delicate crest begins medially under its ventral edge, later being displaced by the posterior face, in order to delimit a ventral face on the lateral two-thirds of the process. The only feature visible is the rugose articular surface, as the remainder of the anterior face is covered by the posterolateral process of the prootic. On the lateral third of the dorsal edge there is a notch, delimiting a small triangular area that might represent a joint with the parietal. The extremity of the process is vertical and slightly rounded.

\section{Lower jaw}

Dentary. This bone is proportionally high, except in its anterior extremity, which is proportionally low (Figures 4 and 5). However, its height does not increase gradually: the bone is very low anteriorly and increases in height sharply posteriorly, and this feature could be related to the great size of the fossil species. In accordance with the shallow anterior extremity, the area of the symphysis is proportionally small (major diameter $\sim 9.0 \mathrm{~mm}$ ). On the lateral surface, four inferior alveolar foramina are visible. There are thirteen preserved teeth (see Dentition). The implantation line is convex anterolaterally (level of the caniniforms), becomes slightly concave (first molariform tooth), and finally is almost rectilinear and somewhat laterally inclined at the last molariform tooth. 

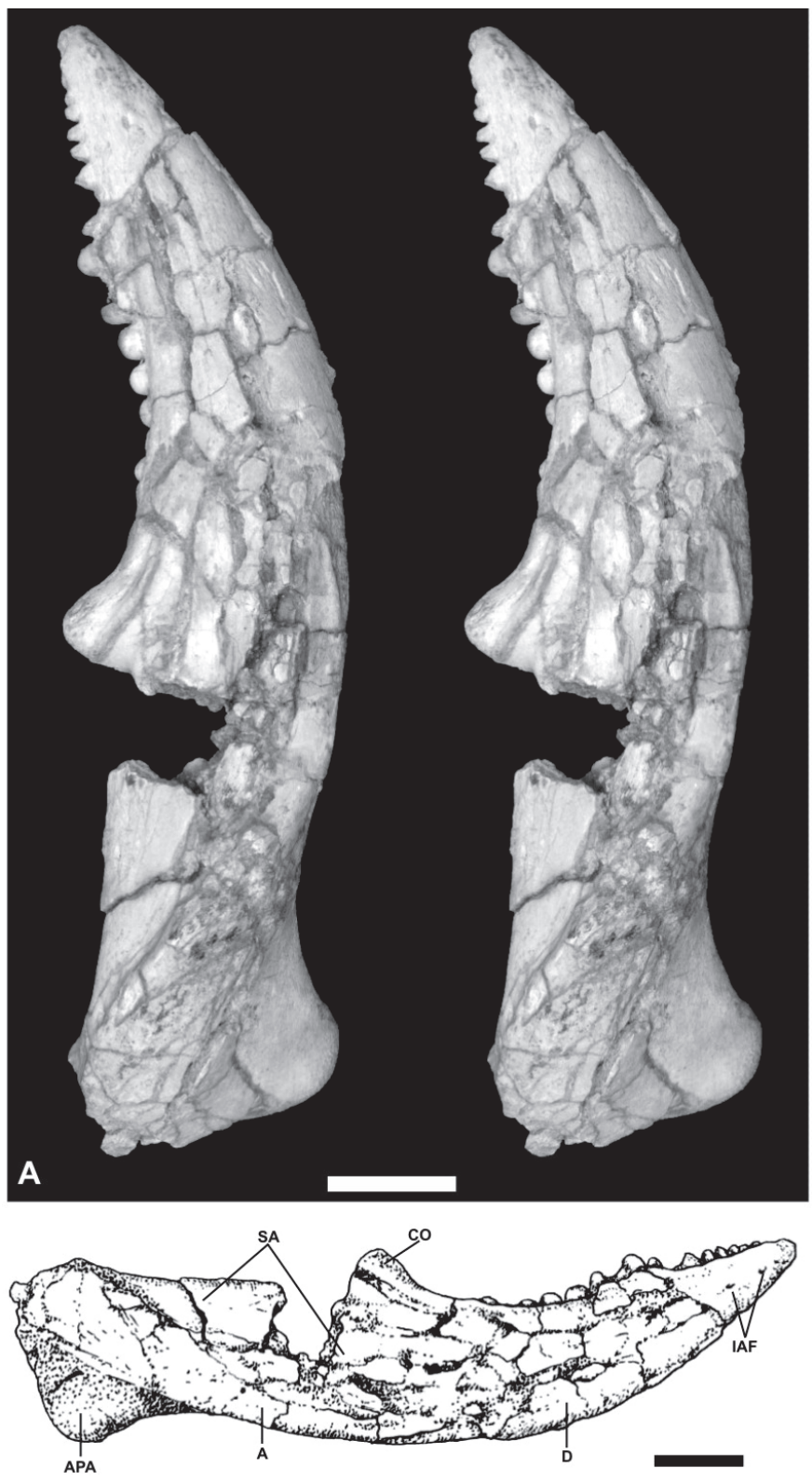

Figure 4. Tupinambis uruguaianensis sp. nov., holotype, MCN-PV 2184. Stereoview and schematic drawings of the lower jaw in lateral (A) and medial (B) views. Scale bars $=20 \mathrm{~mm}$.

Splenial. Like the dentary of the new species, the splenial extends onto the medial surface, as in extant species of Tupinambis. The lower jaw is higher and the splenial is proportionally deeper (Figures 4 and 5). Anteriorly very thin (small fragment isolated), it extends as a wedge between the dorsal/ventral edges of the dentary. Posteriorly, it increases in height up to the level of the antepenultimate molariform; from here it decreases slightly in height until its posterior limit. Two oval foramina are located relatively close each other $(\sim 5.0 \mathrm{~mm})$; the larger $(\sim 5.0 \mathrm{~mm})$ and slightly more dorsal is the anterior inferior alveolar foramen, and the small posterior foramen $(\sim 3.0 \mathrm{~mm})$, is the anterior mylohyoid foramen. The first is located at the level of the junction between the third and fourth molariforms, and the second lies at the level of the fifth molariform.
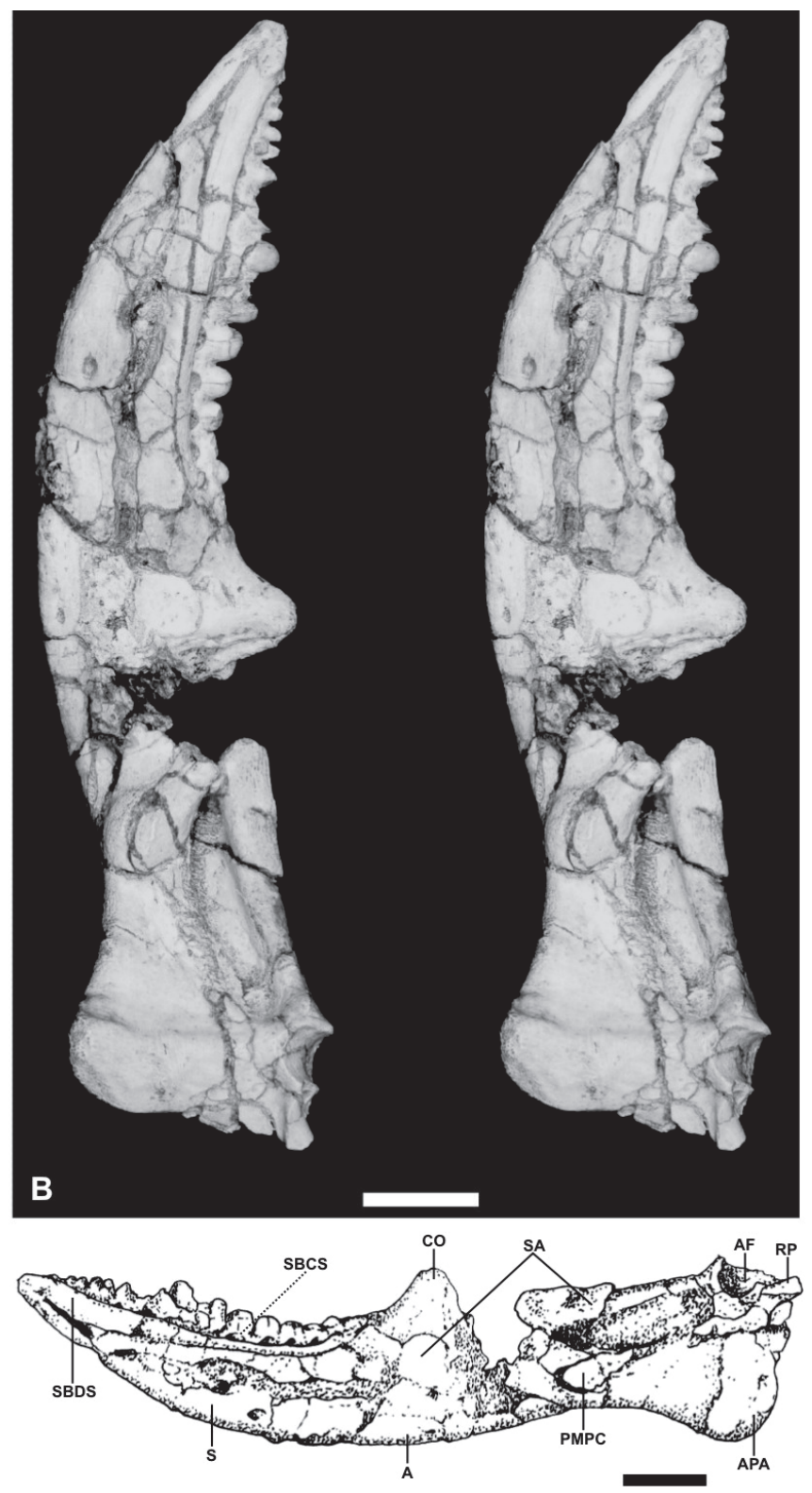

Coronoid. The coronoid is a small complex bone, with four processes (Figure 4). The dorsal process is inclined in an anterolateral to posteromedial direction, has a rounded free edge (dorsal), with a long base, and a steeply inclined anterior edge. A narrow, but prominent crest begins from the posterior edge of the dorsal process, and extends on to the lateral surface of the dorsal and lateral edges, until it makes contact with the dentary. The lateral process is long, and is more or less vertically aligned with the anterior extremities of the angular and surangular bones. The anteromedial process surrounds the posterior edge of the dentary ventrally, and together with the lateral process encloses the dentary. The posteromedial process (posteriorly displaced due to breakage) is long and posteriorly inclined and forms the anterior portion of the ventral edge of the adductor fossa. A medial crest 

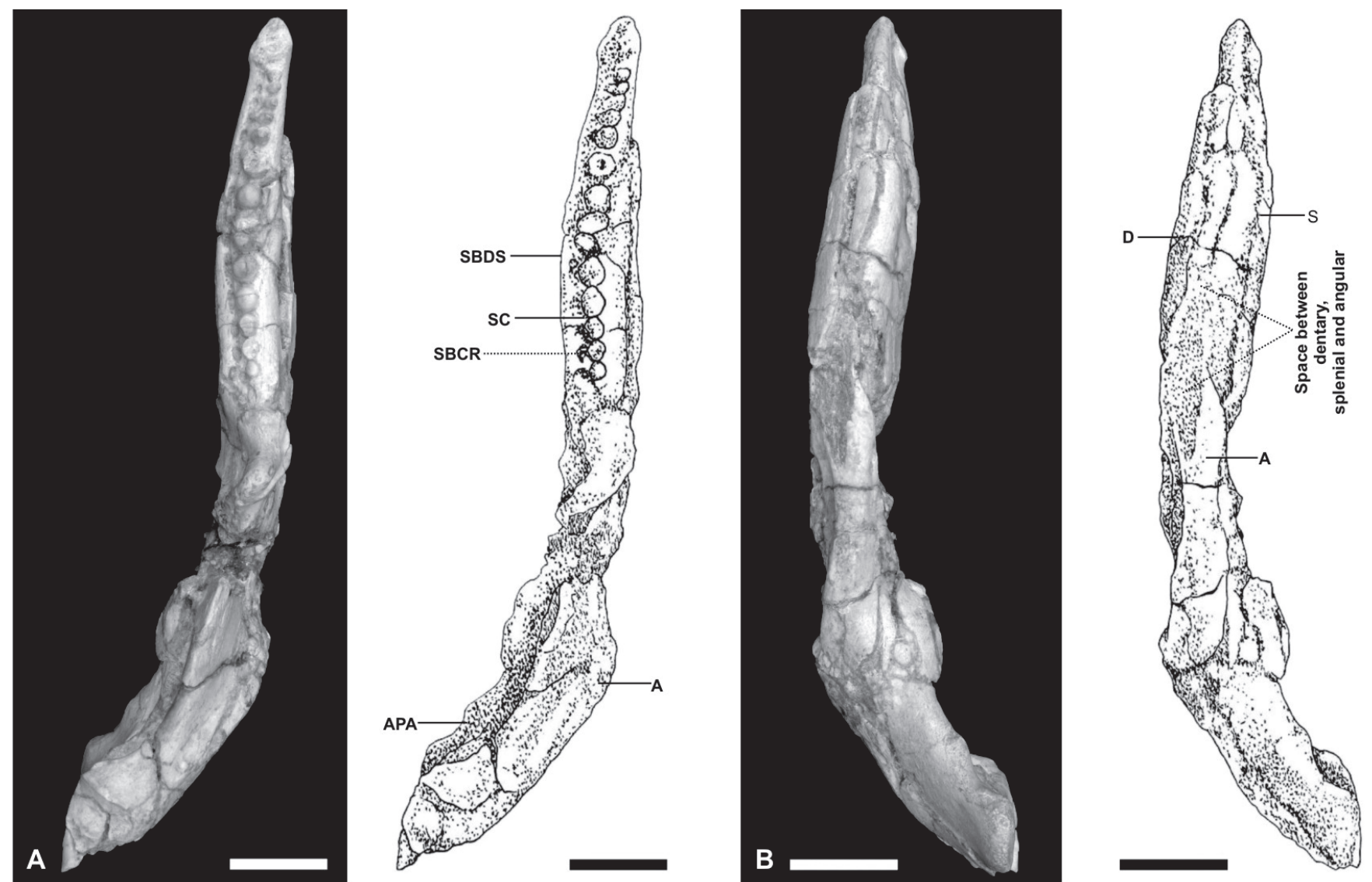

Figure 5. Tupinambis uruguaianensis sp. nov., holotype, MCN-PV 2184. Lower jaw and schematic drawings in occlusal (A) and ventral (B) views. Scale bars $=20 \mathrm{~mm}$.

begins at the posterior edge of the dorsal process, and continues as a more prominent lateral crest that extends along the posteromedial process its anteroventral tip, where it loses height and becomes imperceptible.

Surangular. Together with the coronoid (anteriorly) and articular (posteriorly), this bone forms the dorsal edge of adductor fossa (Figure 4). This edge is broken more anteriorly, but it is rounded in the middle part and more cylindrical anterior to the articular surface (craniomandibular joint) for the quadrate, where a thinner crest, oblique in medial and posterior directions, joins the anterior edge of the craniomandibular joint. The surangular forms most of the lateral surface of the lower jaw between the dentary and the dorsal portion of the adductor crest. A delicate depression seems to mark the position of the anterior surangular foramen, posterior to the surangular/dentary suture and ventral to the dorsal process of the coronoid. The anterior surangular foramen is visible ventral to the anterior edge of the dorsal process of the coronoid. The much smaller posterior one, lies near the dorsal extremity of the angular, slightly dorsal and medial to the dorsal edge of the adductor crest.

Angular. This is a relatively small bone (Figures 4 and 5). It shows a predominantly lateral exposure, between the surangular, the dentary anteriorly, and the articular posteriorly. On this surface is most of the prominent adductor crest (Gao \& Norell, 2000). The bone (and the crest) extends along the ventral edge of the lower jaw, but curves anteromedially to form a wedge that articulates with the dentary laterally and the splenial medially. This anteromedial process contains a small posterior mylohyoid foramen. The marked lateral projection of the adductor crest gives the characteristic shape of the lower jaw of the new species, because it runs in most part of the dorsal surface of the angular bone, in posterior to the anteromedially directions.

Articular/prearticular complex. These bones are fused to each other and with the surangular, forming most of the medial and lateral surfaces of the postcoronoid portion of the lower jaw (Figures 4 and 5). The ventral edge of the adductor fossa (prearticular region) is rounded and is projected medially. More anteriorly, the articular contacts the posteromedial process of the coronoid. The craniomandibular joint is small but very wide, oval and deep, limited anteriorly by a high but delicate crest. As in other lizards, the anterior high crest, could limit the movement of the quadrate. Below the posterior edge of the adductor fossa, there is a prominent, rounded crest, that extends ventrally until to the anterior edge of the angular process. It separates two distinct areas: the portion posterior to the crest is slightly convex and extends ventral to the retroarticular process. Just ventral to the craniomandibular joint, there is a discrete shallow fossa. The angular process is larger, oval and rugose, and has a rounded edge projecting beyond the adjacent ventral and posterior 

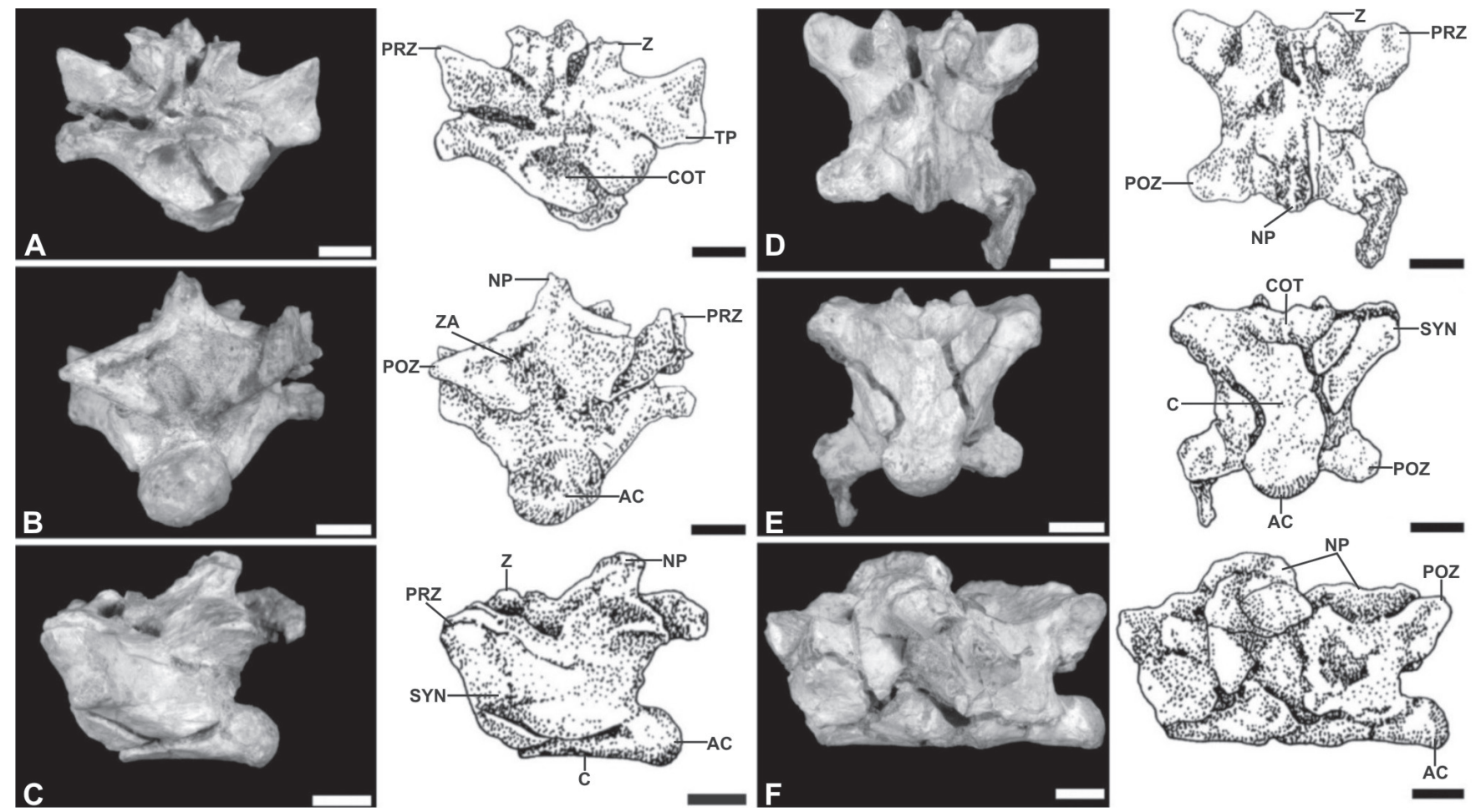

Figure 6. Tupinambis uruguaianensis sp. nov., holotype, MCN-PV 2184. Two dorsal articulated vertebrae and schematic drawings in anterior $(\mathbf{A})$, posterior $(\mathbf{B})$, lateral $(\mathbf{C})$, dorsal $(\mathbf{D})$, ventral $(\mathbf{E})$ and lateral $(\mathbf{F})$ views. Scale bars $=5 \mathrm{~mm}$.

edges. Anterior to the thick vertical crest and ventral to the adductor fossa, the medial surface of the postcoronoid portion is markedly concave, extending up to the concave ventral edge of the articular, and then to the front of the angular process. Although it lacks its extremity, the retroarticular process is relatively thick, with a posteriorly directed apex. Just behind the craniomandibular joint, there is a small foramen for the chorda tympani branch of the facial nerve (cn.VII). The lateral surface of the articular is almost flat and slightly concave up to the edge of the angular process. Due to the accentuated prominence of the adductor crest, this surface is strongly inclined ventrally. This is not caused by the bone as a whole, but only by the crest. Beyond the prominence of the angular process, the most important feature on this surface is a markedly concave ventral edge (from the angular process until the prominence of the posteromedial process of the coronoid).

Dentition. The dentition is heterodont (Figures 4 and 5). The anterior "caniniform" teeth are unicuspid, and posteriorly recurved. The posterior "molariform" teeth are lower and rounded. The implantation is subpleurodont with visible thickening at the tooth base, caused by deposition of cementum (Estes et al., 1988). While the buccal edge of the jaw is high, the subdental shelf is located ventrally several millimeters from the tooth base. Between the subdental shelf and the tooth base, there are deep subcircular cavities, one for each tooth; these pits ("alveoli of substitution" of Barberena et al., 1970) are related to the replacement teeth. At least, 13 teeth are preserved, but two or three anterior caniniforms had been lost by the taphonomic processes; consequently, the dental series had between fifteen and sixteen teeth in life: seven or eight caniniforms, and eight molariforms. Although they had lost the apex, the five caniniforms are conical and must have been somewhat posteriorly recurved. Behind these are eight relative low globular molariforms, with a circular cross-section in the first five and a more oval cross-section in the last three. The molariforms are distinct in their preservation: the first molariform ("the tooth of transition" caniniform-molariform, usually high but without curved apex) is mainly lost the second molariform is the largest of the series (Table 1); the third molariform has only its distal half preserved; the fourth and fifth molariforms are practically complete; sixth and seventh molariforms had lost their occlusal half; and the eighth molariform tooth is also almost complete. Except for the first three that are very similar in size (Table 1), the other molariforms decrease somewhat in their buccolingual

Table 1. Measurements (mm) of the mesiodistal (MD) and buccallingual (BL) tooth diameter of Tupinambis uruguaianensis sp. nov., MCN-PV 2184.

\begin{tabular}{c|c|c}
\hline Tooth & MD & BL \\
\hline $5^{\circ}$ caniniform & 3.4 & 3.1 \\
$2^{\circ}$ molariform & 4.6 & 4.4 \\
$4^{\circ}$ molariform & 4.5 & 4.0 \\
$5^{\circ}$ molariform & 4.0 & 4.1 \\
$6^{\circ}$ molariform & 3.8 & 3.6 \\
$7^{\circ}$ molariform & 3.5 & 3.3 \\
$8^{\circ}$ molariform & 3.2 & 2.8 \\
\hline
\end{tabular}



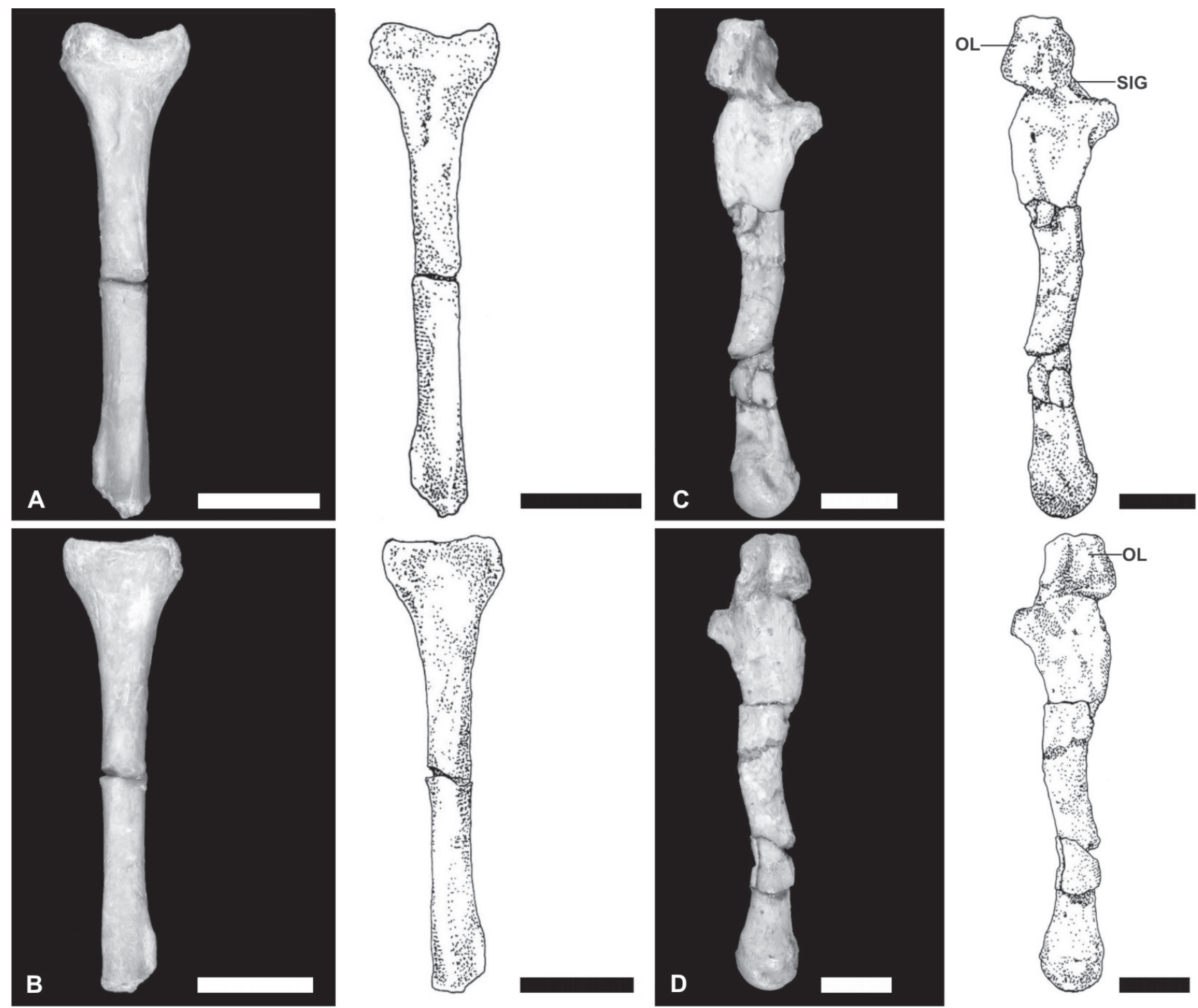

Figure 7. Tupinambis uruguaianensis sp. nov., holotype, MCN-PV 2184. Left radius in anterior (A) and posterior (B) views with schematic drawings; ulna in anterior (C) and posterior (D) views with schematic drawings. Scale bars $=10 \mathrm{~mm}$.

diameter. While the first five are almost circular in crosssection, the last three are oval (larger diameter: mesiodistally). In the better preserved molariforms, extremely delicate ornamentation is observed. At the apex, there is a very low cuspid (due in part to erosion) with radial grooves that run in all directions. The "mesial and distal cuspids", as described by Barberena et al. (1970), are not preserved in Tupinambis uruguaianensis sp. nov. In extant specimens such cuspids are more common in oval posterior teeth, as observed by the above authors. Moreover, in the specimens that we examined (e.g., MCN-R 15245, MCN.D. 299) the mesial cuspid is much larger than distal one, and also than the central cuspid of the tooth. All three cuspids are placed on a mesiodistal crest.

\section{Postcranium}

Vertebrae. These have the usual morphology found in the dorsal region of Tupinambis, but they are larger (Figure 6). The centrum is ovoid in ventral view, wider dorsally and narrower ventrally. Along ventral midline there is a low, rounded crest that joins the ventral edges of cotyle/condyle. The cotyle is wider and higher than the condyle. While the cotyle is more markedly concave (articular facet) ventrally than dorsally, the condyle is more convex dorsally than ventrally. The surfaces of both the cotyle and condyle are somewhat inclined, on the cotyle oriented somewhat ventrally, and on condyle somewhat dorsally. Although broken, the neural spine is low, short (anteroposteriorly) and posteriorly inclined. The prezygapophysis is a little larger than the postzygapophysis, both slightly inclined, medially and laterally, respectively. The zygosphene is much larger (about $50 \%$ more than the prezygapophysis), and is more inclined ventrally than laterally. The zygantrum is coated with $\mathrm{CaCO}_{3}$, which does not allow a more detailed study. The transverse process is projects slightly and has a small rounded synapophysis, not continuous with the prezygapophysis. The morphology of these vertebrae suggests that they belong 


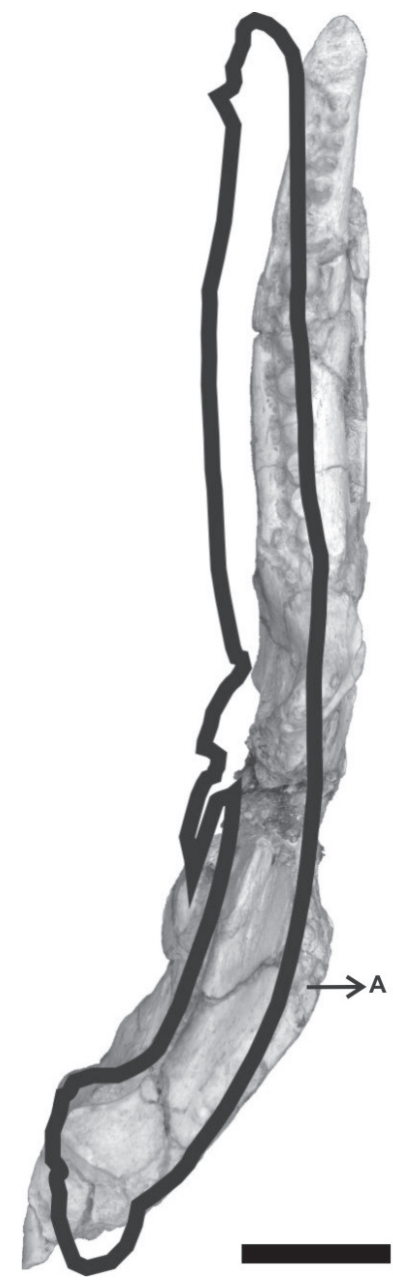

Figure 8. Lower jaw outlines of Tupinambis uruguaianensis sp. nov., (holotype, MCN-PV 2184) and Tupinambis merianae (MCTAN 1132, black line) in oclusal view, showing the adductor crest very pronounced laterally $(\mathbf{A})$. Scale bar $=20 \mathrm{~mm}$.

to the more posterior dorsal region (abdominal region), as shown by the morphology and the synapophysis position. This is very similar to the condition in Tupinambis merianae (see Krause, 1978a).

Radius and UIna. These bones also show the usual morphology found in Tupinambis (see Krause, 1978b, 1990), but are larger (Figure 7).

\section{DISCUSSION}

The fossil specimen is of an adult individual, since the only suture still not fused completely is that between basioccipital and parabasisphenoid bones. However, this is not corroborated by the molariform dentition because there is still a tiny crest and a delicate central cuspid, which suggests that tooth replacement had not yet ceased.

Tupinambis uruguaianensis sp. nov. shows a general morphology similar to that of Tupinambis species (e.g. T. merianae, Barberena et al., 1970), but some characters distinguish it from all the extant species for this genus. While the differences in the braincase are few, there are more in the lower jaw, particularly in the angular and articular bones. The fossil specimen is also larger for all the specimens compared.

\section{Braincase}

The most important difference (but it could be associated with the great size of the fossil), in the braincase between the fossil specimen and extant material, is that the ventral surface of the basioccipital is less concave. This should be related to the orientation of the basal tubera. In the fossil, the basal tubera project more laterally than ventrally and are more horizontal than all compared specimens. This is particularly evident in the horizontal orientation of its anterior and posterior edges. The ventral portion of the crista tuberalis in Tupinambis uruguaianensis sp. nov. seems more vertical, but could be related only to the size of the specimen. According to Bever et al. (2005), the most pronounced ontogenetic change in the basioccipital is the increased development of the basal tubera, these changes also were reported for some lacertids and skinks, due to the increase of the body size.

Because the suture between the prootic and otooccipital is completely fused, it was not possible to determine whether the anterior edge of fenestra ovalis is formed by the prootic, as has been considered by some authors for Tupinambis merianae (e.g., Barberena et al., 1970), for other Teiidae (Alvarez et al., 1987; Tedesco et al., 1999), and other lizards (Oelrich, 1956; Torres-Carvajal, 2002; Bell et al., 2003;

Table 2. Measurements of the total length (TL) in mm of lower jaw in the fossil (T. uruguaianensis) and in the extant species of Tupinambis.

\begin{tabular}{l|c|c}
\hline \multicolumn{1}{c|}{ SPECIMEN } & SPECIES & TL \\
\hline MCN-PV 2184 & T. uruguaianensis sp. nov. & 155.1 \\
MCN-D 298 & T. merianae & 74.0 \\
MCN-D 299 & T. merianae & 105.8 \\
MCN-D 300 & T. merianae & 100.9 \\
MCN-R 15215 & T. merianae & 106.6 \\
MCP-AN 706 & T. merianae & 121.0 \\
MZUSP 84998 & T. merianae & 80.0 \\
MZUSP 85000 & T. merianae & 67.0 \\
MZUSP 91508 & T. merianae & 61.5 \\
MZUSP 84921 & T. quadrilineatus & 64.5 \\
MZUSP 84928 & T. quadrilineatus & 44.5 \\
MZUSP 93082 & T. rufescens & 94.0 \\
MZUSP 93083 & T. rufescens & 78.0 \\
MZUSP 93084 & T. rufescens & 85.0 \\
UFRGS 0122 & T. teguixin & 92.2 \\
MZUSP 92087 & T. teguixin & 75.0 \\
MZUSP 92149 & T. teguixin & 79.2 \\
MZUSP 92131 & T. duseni & 96.0 \\
\hline
\end{tabular}




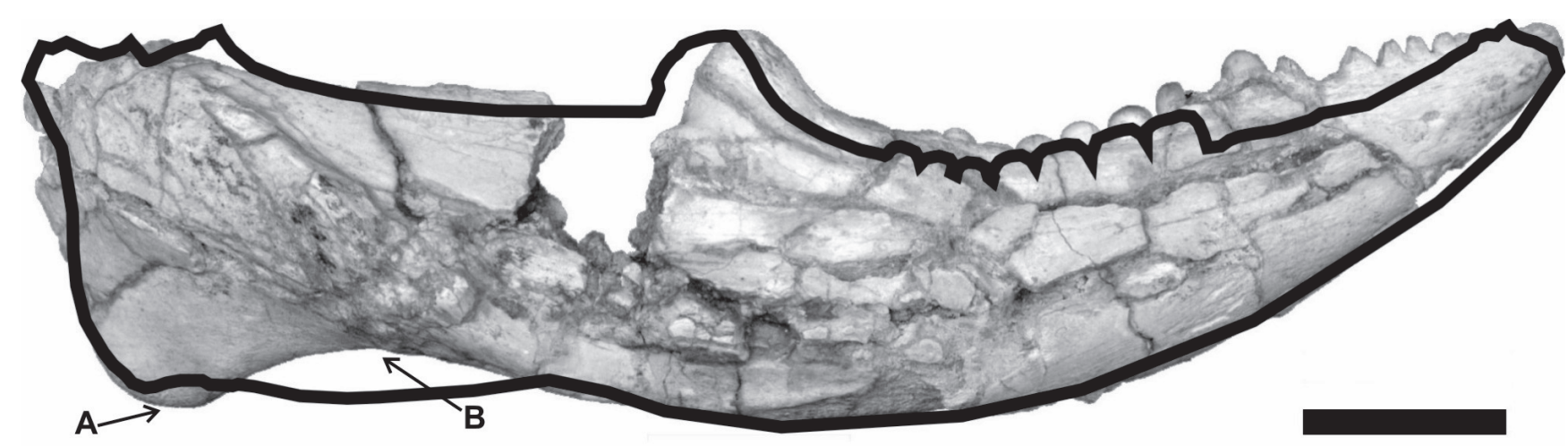

Figure 9. Lower jaw outlines of Tupinambis uruguaianensis sp. nov., (holotype, MCN-PV 2184) and Tupinambis merianae (MCP-AN 1132, black line) in lateral view showing the angular process $(\mathbf{A})$ and ventral edge of the articular bone $(\mathbf{B})$ Scale bar $=20 \mathrm{~mm}$.

Conrad, 2004; Bever et al., 2005). To clarify this point, it is necessary to examine specimens where the prootic/ opisthotic is still not fused but where the growth to this level has already ceased. Although the fossil specimen did not provide evidence of the formation of the fenestra ovalis edges, some youthful specimens of T. merianae (e.g. MCN.D. 301) have supplied some data. Among them, the anterior edge of fenestra ovalis is not yet complete, which could be interpreted as the prootic forming the anterior edge. However, in the specimen MCN.D. 299 (T. merianae), a delicate osseous bar is seen forming the most dorsal part of the anterior edge of the fenestra, osseous bar formed by the otooccipital. Thus, at least in this species, the anterior edge of the fenestra is all formed by the otooccipital, or at least its more dorsal part is.

\section{Lower jaw}

In the lower jaw, Tupinambis uruguaianensis sp. nov. shows the synapomorphies of the Teiidae: hypertrophied splenial, replacement teeth developing in deep subcircular cavities at tooth bases, deposit of cementum on tooth bases, subpleurodont tooth implantation, subdental shelf and sulcus dentalis (Estes et al., 1988; Gao \& Fox, 1996), and shares many characters with the extant species of Tupinambis. However, it differs from these in size (Table 2) and in morphology, mainly of the structures associated with the angular and articular. According to some authors (MacLean, 1974; Gao \& Fox, 1996) that recognized in large size adult specimens of Tupinambis does not exist the subcircular cavities at tooth bases, indicating the suppression of replacement teeth in adults, as in the specimen MCT-AN 1132 (Tupinambis merianae), that was mainly used in the comparative analyses with Tupinambis uruguaianensis sp. nov. (Figures 8 and 9).

In the postcoronoid portion, the great difference of Tupinambis uruguaianensis sp. nov. is in the lateral surface. The adductor crest is very pronounced laterally (Figure 8), which makes the lateral face of the articular particularly ventrally inclined, although medially it does not have a corresponding inclination. The recent species of Tupinambis do not present such lateral projection of the adductor crest, it's more gradual and continuous with the angular bone. Functionally, the crest provides strong insertion for a powerful adductor muscle to move a very heavily built lower jaw (Gao \& Norell, 1998).

Another peculiarity of the postcoronoid region is the morphology of the angular process and the ventral concavity of the articular, anterior to the process (Figure 9). The process is more rounded, and proportionally larger than in the extant species of Tupinambis, projecting beyond the ventral and posterior adjacent limits (Figure 9). According to Bell et al. (2003), the size of the angular process is proportional to the size/age of the individuals, but this feature does not seem to be related with the size/age in the fossil species, because the morphology of the angular process that is distinct from the extant species of Tupinambis (Figure 9). The ventral edge is markedly concave in the fossil specimen, while that in $T$. duseni (MZUSP 92131), T. rufescens (MZUSP 93082, 93083 and 93084) and T. quadrilineatus (MZUSP 84921 and 84928) is clearly rectilinear. In T. teguixin (MZUSP 92149 and 92087; UFRGS 0122) and T. merianae (MZUSP 84998, 85000 and 91508; MCN.D. 298, 299, 300 and 301; MCN-R 15215; MCPAN 706 and 1132), there is also a concavity, but this is not at the ventral edge (Figure 9). In fact, it is exactly in the most ventral portion of the lateral face of the articular, between the angular process and the almost straight ventral edge.

Other differences between Tupinambis uruguaianensis sp. nov. and the extant species of Tupinambis, but perhaps less significant, are the following: (i) the dorsal process of the coronoid is relatively lower, more rounded and with longer base; (ii) perhaps related to its height, the anterior edge of the coronoid process seems to be more anteriorly inclined (less vertical) in T. uruguaianensis sp. nov. than in comparable extant specimens, although in T. merianae as well as other species, there is variation in this angle, with large specimens show in a more vertical anterior edge, while in small specimens, the angle varied more; (iii) both fossae, anterior to the angular process and ventral to the retroarticular process (medial face) are very shallow; (iv) (related to "ii") there is a very open angle between the medial 
face of the articular and the vertical face of the most posterior portion of the lower jaw $\left(\sim 120^{\circ}\right.$; in comparative extant specimens, $\sim 90^{\circ}$ ); and (v) the posteromedial process of the coronoid reaches much closer to the ventral edge of the lower jaw than in the extant species, which could be related to the marked ventral concavity of the articular bone.

Tupinambis uruguaianensis sp. nov. also shares a few characters, whose importance has not yet been determined with other teiid genera. One of these is the apparent alignment of the anterior extremity of the anteromedial process of the coronoid, of the angular and the surangular, despite the breaks. This occurs in Paradracaena and Crocodilurus, but only in some specimens of Tupinambis, in according to Sullivan \& Estes (1997). The marked convexity of the ventral edge of dentary is also found in Dracaena, a large robust teiid lizard. In Dracaena and Paradracaena, Sullivan \& Estes (1997) described grooves in the molariform teeth, which according to them, differ from any another condition in Teiidae. However, such grooves are present in the specimens of Tupinambis merianae examined (as already described by Barberena et al., 1970), as well in the new fossil species T. uruguaianensis.

\section{CONCLUSIONS}

The new Teiidae, Tupinambis uruguaianensis, is the first record of a Squamata from the Late Pleistocene of the Rio Grande do Sul State, Brazil. It has many similarities with the living species of Tupinambis, but is distinguished from all them based on following characters: adductor crest very protuberant, so that the lateral articular bone is lateroventrally directed, an articular bone with a deeply concave ventral margin, and the angular process is more rounded, proportionally larger and projecting beyond the ventral and posterior adjacent limits. Due to the absence of these features in modern Tupinambis species, associated with the larger size between the fossil and adult extant species, the fossil material represents a species distinct from T. merianae. Tupinambis uruguaianensis sp. nov. shows a set of the characters based on comparison between the fossil and extant material. In this way, Tupinambis uruguaianensis sp. nov. is morphologically similar with $T$. merianae, with some features clearly shared by the latter taxon.

\section{ACKNOWLEDGMENTS}

The author thanks the Conselho Nacional de Desenvolvimento Científico e Tecnológico (CNPq) for financial support as fellowship of the Programa de Pós Graduaçào em Geociências (UFRGS). Thanks go also to J. Ferigolo (MCN/FZBRS) and A.M. Ribeiro (MCN/FZBRS) for the critical review of the manuscript and all the incentive and help; to L. Krause (UFRGS) for help with extant teiid lizards; to J.C. Cisneros (UFRGS) and E.C. Holanda (UFRGS) for many suggestions; to T.V. Oliveira (UFRGS) for the drawings presented in this paper and to L.F. Lopes (UFRGS) for the photos.

\section{REFERENCES}

Alvarez, B.B.; Tedesco, M.E. \& Porcel, E. 1987. Osteología craneana de Teius teyou (Daudin, 1802), (Reptilia: Teiidae). Cuadernos de Herpetología, 3(2):7-31.

Ameghino, F. 1893. Sobre la presencia de vertebrados de aspecto Mesozóico en la Formación Santacruceña de Patagonia Austral. Revista del Jardín Zoológico de Buenos Aires, 1:75-84.

Ávila-Pires, T.C.S. 1995. Lizards of Brazilian Amazonia (Reptilia: Squamata). Zoologische Verhandelingen, 299:1-706.

Báez, A.M. \& Gasparini, Z.B. 1977. Orígenes y evolución de los anfíbios y reptiles del Cenozóico de América del Sur. Acta Geológica Lilloana, 14:149-232.

Barberena, M.; Gomes, N. \& Sanchotene, L. 1970. Osteologia craniana de Tupinambis teguixin. Publicação Especial da Escola de Geologia da UFRGS, 21:1-32.

Bell, C.J.; Evans, S.E. \& Maisano, J.A. 2003. The skull of the gymnophthalmid lizard Neuticurus ecpleopus (Reptilia: Squamata). Zoological Journal of the Linnean Society, 139:283304.

Bever, G.S.; Bell, C.J. \& Maisano, J.A. 2005. The ossified braincase and cephalic osteoderms of Shinisaurus crocodilurus (Squamata, Shinisauridae). Palaeontologia Electronica, 8(1): 1-36.

Bombin, M. 1976. Modelo paleoecológico evolutivo para o Neoquaternário da Região da Campanha-Oeste do Rio Grande do Sul (Brasil) - A Formação Touro Passo, seu conteúdo fossilífero e a pedogênese pós-deposicional. Comunicações do Museu de Ciências da PUCRS, 15:1-90.

Brizuela, S. \& Albino, A. 2004. The earliest Tupinambis teiid from South America and its palaeoenvironmental significance. Journal of Herpetology, 38(1):113-119.

Camolez, T. 2006. Levantamento, identificação e descrição da fauna de Squamata do Quaternário brasileiro. Instituto de Biociências da Universidade de São Paulo, Master Thesis, 224 p.

Camolez, T.; Zaher, H. \& Kipnis, R. 2005. A fauna de Squamata do Quaternário superior encontrada em três sítios arqueológicos no Estado de Minas Gerais. In: CONGRESSO LATINOAMERICANO DE PALEONTOLOGIA DE VERTEBRADOS, 2, 2005. Boletim de Resumos, Rio de Janeiro, p. 64-65.

Cei, J.M. \& Scolaro, J.A. 1982. Geographic distribution: Tupinambis rufescens. Herpetological Review, 33:26.

Chani, J. 1976. Relaciones de um nuevo Teiidae (Lacertilia) fósil del Plioceno superior, Callopistes biscuspidatus n. sp. Revista del Instituto Miguel Lillo, 1:133-153.

Conrad, J.L. 2004. Skull, mandible, and hyoid of Shinisaurus crocodilurus Ahl (Squamata, Anguimorpha). Zoological Journal of the Linnean Society, 141:399-434.

Da Rosa, A.A.S. 2003. Preliminary correlation of fluvial deposits at the extreme west of Rio Grande do Sul State, southern Brazil. In: LATINAMERICAN CONGRESS OF SEDIMENTOLOGY, 3, 2003. Abstracts, Belém, MPEG, p. 243-245.

Da Rosa, A.A.S. \& Milder, S. E. S. 2001. Aloformação Guterrez: uma nova unidade estratigráfica para o extremo oeste do Estado do Rio Grande do Sul. In: CONGRESSO DA ABEQUA, 7, 2001. Boletim de Resumos, Imbé, UFRGS, p. 253-254.

Donadio, O.E. 1983. Estado sistemático de los representantes fósiles del género Tupinambis en Argentina (Squamata, Sauria, Teiidae) y consideraciones paleoambientales. Boletín de la Asociación Herpetológica Argentina, 1(3):8.

Donadio, O.E. 1984a. Los lacertílios fósiles de la Província de Córdoba (Sauria, Teiidae) y sus implicancias 
paleoambientales. In: CONGRESSO ARGENTINO DE PALEONTOLOGÍA Y BIOESTRATIGRAFÍA, 3, 1984. Actas, Corrientes, p. 217-223.

Donadio, O.E. 1984b. Teídeos del Mioceno temprano (Squamata, Sauria) de la Província de Santa Cruz, Argentina. Circular Informativa de la Asociación Paleontológica da Argentina, 13:2.

Donadio, O.E. 1985. Un nuevo Lacertílio (Squamata, Sauria, Teiidae) de la Formación Lumbrera (Eoceno temprano), Província de Salta, Argentina. Ameghiniana, 22:221-228.

Estes, R. 1961. Miocene lizards from Colombia, South America. Breviora, 143:1-11.

Estes, R. 1983. Sauria terrestria, Amphisbaenia. In: P. Wellnhofer (ed.) Handbuch der Paleoherpetologie, Gustav Fisher Verlag, Teil 10A, $249 \mathrm{p}$.

Estes, R.; De Queiroz, K. \& Gauthier, A. 1988. Phylogenetic relationships within Squamata. In: R. Estes, \& G. Pregill (eds.) Phylogenetic Relationships of the Lizards Families, Stanford University Press, p. 119-281.

Gao, K. \& Fox, R.C. 1996. Taxonomy and evolution of late Cretaceous lizards (Reptilia: Squamata) from Western Canada. Bulletin of Carnegie Museum of Natural History, 33:1-100.

Gao, K. \& Norell, M.A. 1998. Taxonomic Revision of Carusia (Reptilia: Squamata) from the Late Cretaceous of the Gobi Desert and Phylogenetic Relationships of Anguimorphan Lizards. American Museum Novitates, (3230):1-52.

Gao, K. \& Norell, M.A. 2000. Taxonomy composition systematics of late Cretaceous lizard assemblages from Ukhaa Tolgod and adjacent localites, Mongolian Gobi Desert. Bulletin of the American Museum of Natural History, 249:1-118.

Gasparini, Z.; de la Fuente, M. \& Donadio, O. 1986. Los reptiles cenozóicos de la Argentina: implicancias paleoambientales y evolución biogeográfica. In: CONGRESSO ARGENTINO DE PALEONTOLOGÍA Y BIOESTRATIGRAFÍA, 4, 1986. Actas, Mendoza, p. 119-130.

Hsiou, A.S. O estado atual do registro fóssil de répteis e aves no Pleistoceno do Estado do Rio Grande do Sul, Brasil. In: WORKSHOP QUATERNÁRIO RS, INTEGRANDO CONHECIMENTOS, 2007. Resumos, Canoas, p. 23-24, Disponível em: http://www.ulbra.br/quaternario/resumos.pdf

Krause, L. 1978a. Osteologia pós-craniana de Tupinambis teguixin (L., 1758) sensu Boulenger, 1885. Parte I: Esqueleto axial (vértebras e costelas) (Lacertilia, Scincomorpha, Teiidae). Revista Brasileira de Biologia, 38(2):481-499.

Krause, L. 1978b. Osteologia pós-craniana de Tupinambis teguixin (L., 1758) sensu Boulenger, 1885. Parte II: Esqueleto apendicular (cintura e membros) (Lacertilia, Scincomorpha, Teiidae). Revista Brasileira de Biologia, 38(3):509-521.

Krause, L. 1990. Morfologia e aspectos funcionais do esqueleto apendicular de macroteiídeos (Sauria, Scincomorpha, Teiidae). Boletim do Instituto de Biociências, 47:1-114.

Lema, T. de. 1994. Lista comentada dos répteis ocorrentes no Rio Grande do Sul, Brasil. Comunicações do Museu de Ciências e Tecnologia da PUCRS, 7:41-150.

MacLean, W.P. 1974. Feeding and locomotor mechanisms of teiid lizards: functional morphology and evolution. Papéis Avulsos de Zoologia, 27(15):179-231.

Maciel, L.; Ribeiro, A.M. \& Sedor, F. 1996. Considerações sobre quelônios fósseis do Quaternário do Rio Grande do Sul, Brasil. Ameghiniana, 33(4):467.

Milder, S.E.S. 2000. Arqueologia do Sudeste do Rio Grande do Sul: Uma perspectiva Geoarqueológica. Curso de Pós-Gradu- ação em Arqueologia, Universidade de São Paulo, PhD Dissertation, $172 \mathrm{p}$.

Nydam, R.L; Eaton, J.G. \& Sankey, J. 2007. New taxa of transversely-toothed lizards (Squamata: Scincomorpha) and new information on the evolutionary history of "teiids". Journal of Paleontology, 81(3):538-549.

Oelrich, T.M. 1956. The anatomy of the head of Ctenosaura pectinata (Iguanidae). Miscellaneous Publications of the Museum of Geology, 94:1-122.

Oliveira, E.V. 1990. Considerações preliminares sobre uma nova fauna de moluscos fósseis da Formação Touro Passo (Pleistoceno superior-Holoceno) - Observações estratigráficas e paleoecológicas. Véritas, 35(137):121-129.

Oliveira, E.V. 1992. Mamíferos fósseis do Quaternário do Estado do Rio Grande do Sul, Brasil. Curso de Pós-Graduação em Geociências, Universidade Federal do Rio Grande do Sul, Dissertação de Mestrado, 118 p.

Oliveira, E.V. 1996. Mamíferos Xenarthra (Edentata) do Quaternário do Estado do Rio Grande do Sul, Brasil. Ameghiniana, 33(1):6575.

Oliveira, E.V. 1999. Quaternary vertebrates and climates from southern Brazil. In: J. Rabassa \& M. Salemme (eds.) Quaternary of South America and Antarctic Peninsula, A.A. Balkema Publishers, p. 61-73.

Peres Jr., A.K. 2003. Sistemática e conservação de lagartos do gênero Tupinambis (Squamata, Teiidae). Programa de Pós-Graduação em Biologia Animal, Universidade de Brasília, PhD Dissertation, 193 p.

Peters, J.A. \& Donoso-Barros, R. 1970. Catalogue of the Neotropical Squamata: Part II, Lizards and Amphibians. Washington, Smithsonian Institution Press, 293 p.

Presch, W. 1970. The evolution of macroteiid lizards, an osteological interpretation. University of Southern California, Ph.D. Dissertation, $255 \mathrm{p}$.

Presch, W. 1973. A review of the tegus, lizard genus Tupinambis (Sauria: Teiidae) from South America. Copeia, 4:740-746.

Presch, W. 1974a. Evolutionary relationships and biogeography of the macroteiid lizards (Family Teiidae, Subfamily Teiinae). Bulletin Southern California Academy of Sciences, 73(1):23-32.

Presch, W. 1974b. A survey of the dentition of the macroteiid lizards (Teiidae: Lacertilia). Herpetologica, 30(4):344-349.

Rieppel, O. \& Zaher, H. The braincases of mosasaurs and Varanus, and the relationships of snakes. Zoological Journal of the Linnean Society, 129:489-514.

Retamoso, J.A.; Da Rosa, A.A.S. \& Kotzian, C.B. 2001. Moluscos fósseis do Quaternário da Região extremo oeste do Rio Grande do Sul. In: CONGRESSO DA ABEQUA, 7, 2001. Boletim de Resumos, Imbé, UFRGS, p. 297.

Ribeiro, A.M.; Alvarenga, H.M. \& Rosenau, M. 1995. Primeiro registro de ave fóssil para a Formação Touro Passo (Pleistoceno superior-Holoceno inferior) do Rio Grande do Sul. In: CONGRESSO BRASILEIRO DE PALEONTOLOGIA, 14, 1995. Atas, Uberaba, p.107.

Souza-Cunha, F.L. \& Magalhães, R.M.M. 1986. A fauna de vertebrados sub-recentes de Cerca Grande, Matozinhos, Minas Gerais. In: CONGRESSO BRASILEIRO DE ZOOLOGIA, 6, 1986. Anais, Rio de Janeiro, SBZ, p. 119-131.

Sullivan, R.M. \& Estes, R. 1997. A reassessment of the fossil Tupinambinae. In: R.F. Kay; R.H. Madden,; R.L. Cifelli \& J.J. Flynn (eds.) Vertebrate Paleontology in the Neotropics, The Miocene Fauna of La Venta, Colombia, Smithsonian Institution Press, p. 100-112. 
Tedesco, M.E.; Krause, L. \& Alvarez, B.B. 1999. Descripción del sincráneo de Ameiva ameiva (Linnaeus) (Squamata, Teiidae). Revista Brasileira de Zoologia, 16(4):1025-1044.

Torres-Carvajal, O. 2003. Cranial osteology of the andean lizard Stenocercus guentheri (Squamata: Tropiduridae) and it's postembryonic development. Journal of Morphology, 255: 94113.

Ubilla, M. 1985. Mamíferos fósiles, geocronología y paleoecología de la Formación Sopas (Pleistoceno Superior) del Uruguay. Ameghiniana, 22(3-4):185-196.

Ubilla, M.; Perea, D. \& Goso, C. 2004. Edades TL/OSL, C ${ }^{14}$ y bioestratigrafía de mamíferos en sedimentos continentales del Norte de Uruguay (Formacion Sopas). In: JORNADAS ARGENTINAS DE PALEONTOLOGIA DE VERTEBRADOS, 20, 2004. Libro de Resúmenes, La Plata, p.62-63.

Received in January, 2007; accepted in August, 2007.
Appendix. Comparative material examined in this study: MCN-R 15215, Tupinambis merianae; MCN-D 298, T. merianae; MCN-D 299, T. merianae; MCN-D 300, T. merianae; MCN-D 301, T. merianae MZUSP 12624, Crocodilurus lacertinus; MZUSP 92074, C. lacertinus; MZUSP 92090, C. lacertinus; MZUSP 40082, Dracaena guianensis; MZUSP 62849, D. paraguayensis; MZUSP 92131, T. duseni; MZUSP 84998, T. merianae; MZUSP 85000, T. merianae; MZUSP 91580, T. merianae; MZUSP 84921, T. quadrilineatus; MZUSP 84928, T. quadrilineatus; MZUSP 93082, T. rufescens; MZUSP 93083, T. rufescens; MZUSP 93084, T. rufescens; MZUSP 92087, T. teguixin; MZUSP 92149, T. teguixin; MZUSP 43042, Tupinambis sp.; MZUSP 90290, Tupinambis sp.; MCP-AN 706, Tupinambis merianae; MCP-AN 1132, T. merianae; UFRGS 0122, Tupinambis teguixin. 